\title{
Serbest ve İç Girişimcilik Karşılaştırılması: Telekomünikasyon Sektörü Girişimcilik Vaka Çalışması
}

\author{
Kutay MUTDOĞAN*
}

ÖZ

Günümüz küreselleşen ve rekabetin hızla yükseldiği iş dünyası için girişimcilik hem bir gereklilik hem de bir zorunluluk haline gelmiștir. Girișimcilik kavramı, aslında tarihin en eski zamanlarından beri insanlığın varolușu ile birlikte düşünülebilecek olsa da iș dünyası kapsamında tanımlanıyor ve inceleniyor olması göreceli olarak yenidir. Günümüzde makro boyutta, ülke ekonomileri için de girişimcilik çok önemli bir kavramdır; kurulacak başarılı her yeni işletme ilgili ülke için sermaye, istihdam, büyüme ve zenginleşme anlamına gelmektedir. Bunun yanı sıra mevcut kurumlar veya süreçler için iyileştirme amacıyla yapılan her türlü yenilik ise farklı isimlerle anılabiliyor olsa da iç girişimciliği tanımlamaktadır. Serbest ve iç girişimcilik aynı kökenden besleniyor ve birbirlerine birçok yönden çok benziyor olsa da, oluşumu, çevresel etkileri ve sonuçları itibarıyla bazı farklıliklarda göstermektedirler.

$\mathrm{Bu}$ araştırmada; Türkiye telekomünikasyon pazarında iki girişimci tarafından kurulmuş bir telekomünikasyon kurumsal bayi firması özelinde serbest girișimcilik ve iç girişimcilik kavramlan incelenmiş ve bu iki kavramın benzer yönleri ve farklı yönleri ortaya koyulmaya çalışılmıştır. Ayrıca araştırmaya konu olan vaka çalışması sayesinde, serbest ve iç girişimcilik kavramlarının, hem organizasyonel hem de bireysel düzeyde incelenmesine imkan tanınmış ve akademi ve iş dünyası uzmanları için ortaya çıkmış sonuçlar paylaşılmışır.

Anahtar Kelimeler: Girişimcilik, serbest girişimcilik, iç girişimcilik, vaka çalışması.

\section{The Comparison Between Free Entrepreneurship and Intrapreneurship: An Entrepreneurship Case Study in Telecommunications Industry}

\begin{abstract}
In today's highly globalized and competitive business world, entrepreneurship, has become not only a necessity but mandotary. Although entrepreneurship has formed and developed since the beginning of humanity, description and definition of it is comperatively new through the business world concept and definitions. Today, entrepreneurship is so important for the governmental economies from the macro perspective that; with the help of each succesful newly established company creates employment, growth, and welfare. In addition to those, although it could be named differently by different sources, creating new solutions to improve the existing ones in an existing organization or process is so called as intrapreneurship. Although free entrepreneurship and intrapreneurship have been fed from the same resources and do have so many similarities, they still do have some different characteristics because of their founding and environmental conditions, and their results.

In this research, by the help of investigating a real life case study, free entrepreneurship and intrapreneurship concepts are compared and both the similarities and the differences inbetween those concepts are tried to be explained. In addition; with the help of projecting the case study, both the free entrpreneurship and intrapreneurship concepts are analyzed both from organizational and personal levels.
\end{abstract}

Keywords: Entrepreneurship, free entrepreneurship, intrapreneurship, case study.

\section{Giriş}

Girişimciliğin, geniş açıdan bakıldığında tarihsel sürecin en başından beri var olduğu fikri kabul edilebilir bir fikirdir. Tarih boyunca, özellikle de yazılı tarihe kadar ulaşılan dönemler başta olmak üzere bulunan tüm yenilikler, tüm hayatta kalma becerileri, inisiyatif kullanıp geliştirdikleri tüm alet, edevat bir anlamda girişimcilik tanımına dahil edilmektedir (Demirez, 2005). Daha sonraları insanoğlunun yerleşik tarım hayatına geçmesiyle birlikte, ihtiyaç fazlası üretilen tarım ürünleri ve elde edilen ürünleri diğerleriyle takas etme uğraşı modern hayattaki ticaret kavramının başlangıcı ve aynı zamanda girişimciliğin de öncül ve etkili örneklerinden biri olarak kabul edilmektedir (Durukan, 2006).

Girişimcilik, göreceli olarak modern dönemlerde ticaret hayatının en başından itibaren, ticareti geliştiren ve büyüten bir role sahiptir. Her ne kadar dünya ticaret tarihinin başlarında böyle bir kavrama yer

*Dr., Hemzi Türkiye Yönetici Ortak, kmutdogan@gmail.com

Makalenin Gönderim Tarihi: 16.03.2020; Makalenin Kabul Tarihi: 03.12.2020 
verilmese de, sonraki yıllarda kavrama ait tanımlamalar farklı araştırmacılar ve sektör uzmanları tarafından yapilmıştrir.

Orta Çağ'da girişimci, üretim ile ilgili operasyonları idare eden profil olarak tanımlanırken; kendi insiyatifi ile ortaya iş koyan kişi değil, bunun yerine mevcutta yürütülen işleri yöneten profil olarak tanımlanmıştır (Sönmez \& Toksoy, 2014). 17.yy’da, günümüz tanımları ile uygun olarak girişimcilik kavramı risk kavramı ile ilişkilendirilmiş ve ilgili kişilerin gelir ve zararları dikkate alma süreci olarak ortaya konmuştur. Ekonomik literatürünün içerisinde girişimcilik kavramı ise; ilk olarak 1730'lu yıllarda Fransız Richard Cantillon tarafindan kullanılmış, devam eden süreçte, John Stuart ise 19. yy'da, girişimcilik kavramını İngiliz literatürüne sokmuştur (Çetindamar, 2002). Francis Walker, 1876 ve 1878 'de yaptı̆̆1 çalş̧malarda (Durukan, 2006), girişimciliğin risk ile ilişskisine ek olarak tanımın içine yöneticilik becerisini de eklemiştir ve sermayenin faiz geliriyle çoğalmasına alternatif olarak paranın yönetim becerileriyle kullanımı kavramını ortaya koymuştur.

Daha sonra, 1934'de Joseph Schumpeter girişimciliği, 'Ekonomik Gelişme Teorisi’ kapsamında incelemiştir. Bu anlamda araştırmacı, girişimciliği; yeni, inovatif ve denenmemiş teknolojileri ilk defa kullanan ve ticarete katan anlamında tanımlamalar yapmışır. Araştırmacı bu yenilikleri; yeni ürünler, henüz kullanılmayan yeni teknolojiler, girilmemiş ya da bilinmeyen bir pazara açllma, ilk defa kullanılacak olan ham madde ile üretilen ürünler, ve endüstrilerin yeniden organizasyonu şeklinde sınıflandırmışır (Schumpeter 1963 (1911), s. 66). Devam eden çalışmalarda, 1960’lı yllarda sırasıyla; 1961'de Frank Knight girişimciliği, risk, belirsizlik ve gelir kavramları ile birlikte incelerken; Harvey Leibenstein 1968'de girişimciliği, gelişme kavramı ile birlikte incelemiştir. Israel Kiznar, 1973'de girişimciliği firmaların birbirleriyle rekabet olgusu içinde incelerken; Mark Casson, 1982'de girişimciliği, bir ekonomik teori çerçevesinde incelemiştir (Sönmez \& Toksoy, 2014).

Yakın tarihte, girişimcilik ile ilgili etki bırakan son araştırmalardan bir tanesi de Peter Drucker'un 1986'da yapmış olduğu çalışmada; girişimcilik, inovasyon ile ilişkilendirilmiş ve bu perspektiften inceleme yapılmıştır (Sönmez \& Toksoy, 2014). Drucker'ın bu çalışmasında; ekonomide firsatları değerlendirmenin en iyi yolunun inovasyon olduğu kadar aynı zamanda girişimciliğin ve girişimcilerin olduğu fikri ortaya konmuştur. Albert Shapero (1982), yapmış olduğu çalışmada girişimciliği; insiyatif kullanılan, hamlede bulunulan, sosyal ve ekonomik süreçlerin bir arada değerlendirildiği ve organize edildiği, ve risk alınan bir süreç olarak tanımlamıştır (Sönmez \& Toksoy, 2014).

Diğer bir araştırmacı Robert Hiscrich ve Peters (2001) ise, konuya farklı bir açıdan yaklaşmıştır. Araştırmacı konuyu mikro düzeyde incelemiş ve insani açıdan tanımlar yapmaya çalışmışır. Araştırmacıya göre, girişimciyi; tüm finansal, psikolojik, ve sosyal risklere rağmen elde edeceği kazanciyla finansal ve bireysel tatmin alan, bunun için zaman ve efor harcayan, ve katma değerli sonuçlar elde etmek isteyen kişiler olarak tanımlamıştır. Diğer bir araştırmacı Kirzner (1960), girişimciliği sosyo-ekonomik açıdan incelemiş ve girişimcilik ile pazar ve tüketici ilişkilerine dikkat çekmiştir (Sönmez \& Toksoy, 2014).

Son dönemlerde yapılan çalşsmalardan Robert, Peters ve Shepherd'in (2005) çalışmasında, girişimciliğin; kişiler arasında farklılaşan bakış açlarıyla da gözlemlenebileceği belirtilmiştir. Bir iş insanı için gereksiz, israf veya sonuçsuz görülebilecek bir girişim bir diğeri tarafindan çok elverişli bulunabilecek ve sonuç da alınabilecektir. Bu da yine girişimciliğin bireysel perspektif ile incelenmesine dikkat çekilmesidir.

Modern zamanlarda, giderek küreselleşen dünyada firmaların rekabet düzeyi çok yüksek seviyelere ulaşmıştır. Bu anlamda firmaların birbirlerinden ayrışabilmesi ve hedef kitlelerine ulaşabilmesi her geçen gün daha zor hale gelmiştir. Firmaların, bu rekabetin altından kalkabilmesi için sürekli ortaya yenilikler koyabiliyor olması çok önemlidir. Bu nedenle yeni ürünler ve/veya yeni yöntemler geliştirebilmek girişimcilik acısından çok anlamlı olabilmektedir.

Girişimcilik, diğer taraftan; bahsedilen yenilikleri ortaya koyarken, aynı zamanda ekonomik katma değer ortaya koyabilmesi için kaynakların en verimli şekilde kullanılması gerekliliğini de beraberinde getirmektedir. Bu anlamda girişimcilik; enerji, teknoloji, hammadde ve sermayeyi akılcı ve bütüncül bir şekilde en verimli ve etkili şekilde kullanabilmektir (Küçükaltan, 2009). Makro düzeydeki etkileri, yani ülkelerin kalkınması açısından da girişimcilik olgusu çok değerlidir. Ülkelerin ekonomik anlamda gelişebilmesi ve büyüyebilmesinin yollarından bir tanesi de o ülkedeki girişimci firmaların dönemin ihtiyaç ve isteklerine uygun yenilikler yapabiliyor olması ve değerlerini arttırması ile doğrudan ilişkili olabilecektir. 


\subsection{Serbest Girişimcilik ile İlgili Özellikler}

Robinson'un (2014) yapmış olduğu çalısmaya göre; başarrlı girişimcilerin sahip olduğu ortak özellikler, azim, tutku, belirsizliklere karşı hoşgörü, vizyoner olma, kendine güven, esneklik, yeni kurallar belirleme gibi başlıklarla ifade edilebileceği belirtilmiştir. Yine, 'Beş Önemli Karakter Özelliği ve Girişim Durumu' isimli eserler serisi üserinde yapılan araşturmalarda serbest girişimcilerle, kurumsal yöneticiler arasındaki farklar irdelenmiştir. Bu araştırmalarda girişimcilerin, kurumsal yöneticilere nazaran açılık, deneyim, merak, inovasyon, dürüstlük, vicdan, disiplin, ve motivasyon alanlarında daha yüksek değerlere sahip oldukları belirtilmiștir. Bu noktada bu araștırmaya da konu olan ve aslında kurumsal yöneticiler olmakla beraber iç girişimci özellikleride bulunan ve buna uygun faaliyetlerde bulunan kişilerle diğer yöneticiler arasındaki ayrımın net bir şekilde yapılması gerekmektedir. Yine Robinson'un yaptı̆̆ çalışmalarda serbest girişimcilerin sahip olması gereken dört önemli yetenek kategorisi olarak; iş yetenekleri, kişisel yetenekler, liderlik yetenekleri, ve girişimcilik yetenekleri olarak ortaya konmuştur. Bu noktada ilgili yeteneklerin, serbest girişimcilerin olduğu kadar iç girişimcilerin de sahip olması gereken yetenekler olduğu net bir şekilde söylenebilecektir. Yine aynı çalışmada bahsedilen yetenek gruplarının içerdiği alt yetenekler şu şekilde belirtilmiştir;

İş Yeteneği: Stratejik düşünme; global perspektif; fırsatları tehditlerden ayırma; sektörel farkındalık yetenekleri.

Kişisel Yetenekler: Kişisel etkinlik; farkındalık; beceriklilik; etkileme gücü; iletişim; yaratıcılık; cesaret; sabir.

- Girişimcilik Yeteneği: Teknik girişimcilik yeteneği; geniş yöneticilik yeteneği; girişimciliği idrak; süreç uzmanlığ1.

- $\quad$ Liderlik Yeteneği: Yüksek seviye liderlik; karar alıcllık.

Araştırmalara göre girişimcinin, başarılı bir girişim sergileyebilmesi için gereken karakteristik özellikler; hedefe yönelik yüksek motivasyon, risk alabilmek, yenilikçi olmak, işle ilgili doğru ve tamamlayıcı bilgilere sahip olmak şeklinde sıralanabilir. Coulter ve Robbins (2003) ve McDaniel (2002) yapmış oldukları çalsşmalarda; başarılı girişimcilerin sahip olması gereken özelliklerin doğuştan gelebileceği gibi, sonradan da edinilebileceği belirtilmiştir. Araşıırmacılar, bu özellikleri şöyle sıralamışlardır; yüksek motivasyon düzeyi, özgüven, uzun dönem için gerekli yetenek, yüksek enerji seviyesi, problem çözmeye yönelik 1srarcılık, yüksek yaratıcılık derecesi, amaçları ortaya koyma yeteneği, gurur, bir görevi başarma ve bitirme azmi, denemeye devam etme 1srarı, hesaplanmış riskleri üstlenme istek ve kabiliyeti, odaklanma, yapılan hatalardan ders çıkarma yeteneği, değer yaratma, firsatlanı görebilmek.

Arrkan (2002), bunlara ek olarak girişimcileri; vazgeçmeyen, belirsizliğe karşı hoşgörülü, detaylara önem veren ve mükemmelliyetçi olarak tanımlamıștır. Derman'a (2002) göre girişimcilik, aynı zamanda krizleri firsatlara dönüştürme becerisine sahip olabilmektir. Bu açıdan girişimcinin, teknik özelliklere de sahip olabilmesi; yani üretim, pazarlama, finansman, ve satış gibi fonksiyonları koordinasyon içerisinde yönetebilmesi de gerekmektedir.

Bazı araştırmacilara göre (Durukan, 2005; Titiz, 1994; Müftüoğlu, 2004; Bozgeyik, 2005) göre başarilı olmaya aday girişimcilerin ortak olabilecek özellikleri şu şekildedir;

Ölçülebilir riskleri göze almak ancak kumar oynamamak.

Kararlı olabilmek.

Çok yönlü olmak.

İs bitirici olmak.

Özgüven sahibi olabilmek ve kişisel değerlendirmeleri yapabiliyor olmak.

İșlerin zamanında tamamlanabilmesi için kararlı olabilmek.

Değişikliklere adapte olabiliyor olmak.

$\mathrm{Bu}$ tanımlara destek olarak Histich ve Peters (2001), yapmış olduğu çalsşmada girişimcilerin sahip olması gereken becerileri üç ayrı grupta sınıflandırmıştır; Teknik Beceriler, Yönetsel Beceriler, Bireysel Beceriler. Hisrich ve Peters'a (2001) göre, bu becerileri tanımlayan alt beceriler şu şekildedir.

Teknik Beceriler; Sözlü iletişim, çevresel gözlem, teknik yönetim belgesi, teknoloji, bireyler arası iletişim, dinleyici olma, örgütleme, şebeke kurabilme, yönetim türü, takım oyuncusu olmak. 
- Yönetsel Beceriler; Amaçları belirleme, karar verme, insan ilisskileri, pazarlama, finans, muhasebe, yönetim-yönetim geliştirme, denetim, sorun çözme, girişim.

- Bireysel Beceriler; İçsel denetim, risk alma, yenilik yapma, değişimi yönetmek, kararlı olmak, vizyon sahibi olmak.

$\mathrm{Bu}$ araştırmaların genel anlamda odaklandığı kavram, girişimciliğin çoğunlukla birey perspektifinden değerlendirilmesidir. Akademisyenlerin genel olarak üzerinde mutabakat sağladıkları görüşe göre (A $\breve{c r a ~ \& ~}$ Yörük, 2006); girişimciler, inisiyatif almakta, kaynakları değerlere dönüştürmekte ve buna uygun olarak sosyal ve ekonomik düzenlemeler yapmakta, ve son olarak risk ve başarısızlığı kabul edebilmektedirler. Tüm bu girişim teşebbüslerinde mutlaka yeni bir fikir vardır ki bu fikir; tamamen bir yenilik olabileceği gibi var olan bir ürün, süreç, ya iş yapış fikrinin yeniden yorumlanması, ya da tamamen sürdürülen bir işin yeni insanlar tarafından organize edilmesi şeklinde meydana gelebilir. Girişimcinin, bu andaki etkinliği bu fikrin ticari bir fırsata dönüşüp dönüşmeyeceğinin kararının verilmesidir. Fikrin, ticari bir firsata dönüşme kararının ardından, gerekli organizasyonel becerileri göstermek ve bu dönüşümü gerçekleştirmek, yine ancak girişimcinin ortaya koyacağı becerilerle mümkün olabilecektir.

Girişimcilerin, başarılı olabilmesi için gerekli olan tüm bireysel özelliklerin en başında sahip olmaları gereken inisiyatif kullanabilme becerileri ve liderlik özellikleri gelmektedir. Girişimcilik olgusunun içine liderlik kavramının da girmesiyle birlikte Jennifer James (1997) yapmış olduğu çalışmada lider vasıflı girişimcilerin sahip olması gereken özellikleri aşağıdaki gibi sıralamıştır (Gül, 2005);

Çevreye farklı bir gözle bakabilmek; Girişimci şahısların, yaptıkları girişim operasyonu anına dek sahip olduğu tüm bilgi, birikim ve tecrübelerin oluşturacağ1 olası işsel körlüklerin önüne geçebilmek adına, tüm ticari ve kişisel özellikleri gözden geçirmek ve yeniden değerlendirme yapmak.

Mit ve sembolleri kullanmak; Taze bir iş veya çalışma ortamı oluşturabilmek adına çevre koşullanı, kültür ve diğer unsurları kullanarak yeni fikirlerin oluşması için imkan sağlayabilmek.

- Geleceği tanımak; Günümüzde yer alan gelişmelerin gelecekle olası bağlantılarını anlamak, öngörmek ve buna göre gerekli hazırlıkları yapabiliyor olmak.

Daha hızlı yanıt vermek; Gerek çevresel gerekse hedef müşteri gruplarındaki meydana gelen değişimleri hızlıca tespit etmek ve bunlara uygun bir biçimde reaksiyon verebiliyor olmak.

Kaynakları akıllıca kullanıyor olmak; Sahip olunan kaynakları en etkili ve verimli bir şekilde kullanabiliyor olmak.

- Çeşitlilikten yararlanma; Hem çalışan hem de müşteri bazında olası tüm dini, kültürel, sosyal, zihinsel farklılılaklardan yararlanmaya çalışmak.

Girişimcilik kavramını tek bir iş kolu veya alanı için kullanmak mümkün değildir; bu kavramı tüm iş alanları için kullanmak mümkündür. Örneğin ekonomide bir girişimci, tüm kaynakları bir araya getiren, öncekinden daha fazla değer yaratan, aynı zamanda değişim ve yenilikçi süreçler oluşturan birey olarak ortaya çıkmaktadır. Diğer taraftan bir bilim dalında çalışan bir akademisyende girişimcilik, mevcut teorilerin ötesinde bulduğu yeni fikirlerle yeni teoriler oluşturan, bunu katma değerli hale getiren ve insanlığa fayda sağlayan birey olarak tanımlanabilecektir.

$\mathrm{Bu}$ araştırmada da belirtildiği gibi girişimcilik tanımının alanı, hedefi ve etkileri ile ilgili çok geniş akademik çalışmalar mevcuttur. Bu araştırma alanlardaki genişlik, odaklanılacak kavramların çok çeşitli olmasından, entegre bir yapının olmayışı ve etkenlerin çok olmasından ötürü girişimcilik ile ilgili genel geçer bir anlayış gelişmesi zor bir hale gelmiştir (A ğca \& Yörük, 2006). Ancak ortak olan tanım; girişimciliğin, finansal firsatların yeni değerlere dönüştürüldüğu süreci olduğudur. İlgili firsatların ise her türlü süreç, birey, yapı, ürün vb. tüm konularda oluşturulan inovatif süreçlerle olduğu fikri birçok araştırmacı tarafından ortaya konmaktadır.

İnovasyon kavramı sadece tamamen yeni bir ürün ya da süreci keşfetmek ve uygulamak anlamına gelmemektedir. İnovatif bir bakış açısıyla, girişimcilik kavramı kapsamında, farklı bakış açılarına dikkat çekebilmek yerinde olacaktır. Robert, Peters, ve Shepherd'a (2005) göre; bir kişi aynı koşulları tehdit ve zorlu bir ortam gibi görürken, diğer yandan bir girişimci aynı koşullardan varlık yaratan, kaynakları daha verimli kullanmanın yollarını bulan, tedarik kaynağı yaratan, müşteri yaratan yeni koşullar ortaya koyabilmektedir. 
Bozgeyik (2005) yapmış olduğu çalısmada, girişimcileri; belirsizlik ve risk koşullarında yeni firsatlar oluşturabilen ve/veya uygun firsat ve sahip olunan kaynakları kazanca dönüştürebilen ve büyüyen iş modelleri ortaya çıkarabilen kişiler olarak tanımlamışırı. Yine Titiz (1994) girişimciyi tanımlarken; risk almadaki yatkınlık ve fırsatları görüp zamanında değerlendiren kişi ifadesini kullanmıştır.

\section{2. İç Girişimcilik Kavramının Oluşumu ve Gelişimi}

The American Heritage Dictionary of English Language (Ağca \& Kurt, 2007), iç girişimciyi (intrapreneur); 'büyük bir firma içinde bir fikri, risk alma ve yenilik yapma yoluyla verimli nihai bir ürüne dönüştürme sorumluluğunu üstlenen kişi’ olarak tanımlamıştır. Miner (1997), yapmış olduğu çalışmada, iç girişimciyi; 'gelir elde etme amaçlı organizasyonlarda içeriği yeniden belirlenmiş bir stratejinin parçası olarak yeni fonksiyonlar geliştiren veya yeni firsatları zorlayan 'yenilikçi yöneticiler" olarak tanımlamıştır.

Akademi ve iş dünyası, iç girişimcilik kavramını 1980'lerden beri analiz etmeye başlamıştır. Bu analizler sonucunda yapılan tanımlamalara göre, 'iç girişimcilik'; organizasyon içindeki kişilerin performansını arttırma ve genel anlamda organizasyonun büyümesi ve gelirlerini arttırması adına öncül fikirler ortaya koyabilmek şeklinde çerçevelenmiştir. İç girişimcilerin ve iç girişimciliğin, firmaların performansı üzerindeki olumlu etkileri akademisyenler tarafindan birçok araştırmaya konu olmuştur. Burgelman (1983, 1985), Pinchot (1985), Rule ve Irwin (1988), Zahra (1991, 1993a, 1993b, 1993c, 1995), Lumpkin ve Dess (1996; 2001), Wiklund ve Shepherd (2005) konuyu tarih akışı içinde inceleyen araştırmacılardan sadece bazılarıdır. Her ne kadar araştırmaların birçoğunda bu analizler, büyük işletmeleri konu alıyor olsa da, ilgili analizlerin küçük ve orta işletmeler için yapıllyor olması da çok anlamlıdır.

Çoğunlukla orta ve büyük işletmeler için yapılan araştırmalarda, araştırmacılar tarafindan iç girişimcilik (intrapreneurship) (Pinchot, 1985; Luchsinger \& Bagby, 1987; Carrier, 1996) kavramina benzer olarak kullanılan başka kavramlar da mevcuttur. Kurum girişimciliği (corporate entrepreneurship), bu kavramlardan bir tanesidir. Genel olarak kurum girişimciliği; kurumların rekabet koşulları içinde ve bu rekabette öne geçebilmek için tasarlanan ürün, süreç ya da strateji konularında tasarlanan ve uygulanan yenilikler ve yeni firsat alanları yaratmak eylemi şeklinde ifade edilmiştir. Kurum girişimciliği ile ilgili çalışmalar yapan araştırmacilardan dikkat çekenleri sıralamak gerekir ise; Vesper (1984), Guth ve Ginsberg (1990), Covin ve Miles (1999), Zahra (1991, 1993a, 1995) en başta gelenler olarak belirtmek mümkün olacaktır.

Araştırmalarda iç girişimcilik ile bir arada kullanılan diğer bir kavram ise 'şirket girişimciliği'dir (corporate venturing). Burada anlatulmak istenen ise; bir kurum içerisinde büyümeye yönelik olarak yeni işlerin yaratılması olarak özetlenmiştir. Bu konuda ise Macmillan ve George (1985), Stopford ve BadenFuller (1994), Miles ve Covin (2002) başlıca araştırmacılar olarak sıralanabilecektir. Yine iç girişimcilik kavramı çatısı alında kullanılan diğer bir kavram ise 'kurum içi girişimcilik'dir (internal corporate intrapreneurship). Bu kavramın içinde de temel olarak bir kuruma bağlı kişi, süreç veya departmanların girişimilik eğilimiyle almış oldukları inisiyatif anlatılmaya çalısıılmaktadır. Bu konuda da Schollhammer (1982), Jones ve Butler (1992) ise önemli çalışmalar yapmış araştırmacılardır. Bahsedilen tüm bu çalışmalar ve girişimcilik ile ilgili yapılmış çalışmalar incelendiğinde, serbest ve iç girişimcilik kavramlarının iç içe geçtiklerini, bazı kavramların farklı çalışmalarda farklı şekillerde açıklandığını, düzenli olarak ek bazı tanımlamalar yapıldığı gözlenebilmektedir. $\mathrm{Bu}$ da girişimciliğe ait kavramların düzenli olarak güncellendiğini ve geliştirildiğini göstermektedir.

\section{3. İç Girişimcilik ile İlgili Tanımlamalar}

Carrier (1996), iç girişimcileri her türlü yenilik oluşturan kişiler olarak tanımlarken, Pinchot (1985) ise herhangi bir yeni iş fikrini firma içinde uygulama sorumluluğundaki kişi olarak tanımlamışır. İç girişimciler her halükarda yeni ürün ya da hizmetler bulan kişiler değildir, aynı zamanda mevcut sistemleri daha çok gelir elde edecek şekilde farklı bir açıdan ele alan ve bu anlamda sistemler kurabilen ve ekipler oluşturabilen kişilerdir. Naktiyok’a (2004) göre; iç girişim hamlesi, girişimcilik ruhu ve etkinliğinin organizasyon içinde gelir getirecek ve organizasyonu büyütecek şekilde kişinin bağlı bulunduğu kurum içinde her türlü aksiyonun alınabilmesidir.

Zahra (1991), yapmış olduğu çalışmada iç girişimcilik ve aynı anlamda kullandığı kurum girişimciliğini; yeni ürünler, süreçler ve/veya yeni pazar veya iş kollarına girmek amacıyla yenilikler yapiyor olmak ve bu 
doğrultuda yapılan biçimsel veya biçimsel olmayan faaliyetler olarak tanımlamıştır. Antoncic ve Hisrich'e (2003) göre iç girişimcilik ile ilgili yapılan araştırmalar üç ana konu üzerinde odaklanmıştır. Bu konulardan ilki, bahsedilen iç girişimciliği tasarlayan ve uygulayan kişilerle ilgilidir ve bu insanların karakter özelliklerine odaklanılmaktadır. Bu araştırmacıların bir kısmı, iç girişimcilik faaliyetlerini uygulayan insanların nitelikleri ve psikolojik özelliklerine odaklanmaktadır. Bunlar arasında Pinchot (1985), Carbone (1986), ve McKinney ve McKinney (1989) sıralanabilmektedir. Bu araştırmacıların ulaşmış olduğu sonuçlardan en göze çarpanı serbest girişimciler ve iç girişimcilerin profillerinin birbirine benzer olduklarına dair yapmış oldukları tespitlerdir.

Illk grup araştırmacının diğer kısmı ise temel olarak iç girişimci olarak tanımladıklanı kişilerin bağlı bulundukları kurumlar içerisindeki rolleri ve fonksiyonlarına odaklanmışlardır. Bu araştırmacılar içerisinde Knight (1987), ilk başta öne çıkanlardan biridir. Genel anlamda bu birinci gruptaki araştırmacıların ikinci kısmının sonuçlarına bakıldığında, iş hayatında da son dönemlerde popüler olan 'değişim ajanları', 'yenilik öncüleri’ gibi kavramların meydana çıkarıldığı gözlemlenmektedir (Carrier, 1996). Bunun yanı sıra, iç girişimciliğin, kurumlar için sağladığı faydalar ve desteklenmesi gerektiği ile ilgili öneriler de bu araştırmac1 grubunun elde ettiği sonuçlar arasında gösterilebilecektir (Antoncic \& Hisrich, 2003).

İç girişimcilik ile ilgili yapılan araştırmaların ikinci ana konusunda ise, iç girişimcilik süreci ağırlıklı olarak incelenmiştir. Bu alanda ortaya çıkan araştırma konusu; iç girişimcilik süreçlerinin, hangi sebeplerle oluştuğu ve/veya ne tip çalışma ortamları oluşturulduğunda ortaya çıktı̆̆ ile ilgili olmuştur (Ağca ve Kurt, 2007). Bu alan; iç girişimcilerin kişisel özelliklerinden ziyade iç girişimcilik ortamını doğru bir şekilde kurgulayan, ve bu anlamda organizasyonel olarak tasarlanan fikirler ve firma yapisı ile ilgili yapılan uygulamaları konu almaktadır. Bu araştırma konusunda çalışma yapan araştırmacılann başlıcalarını; Covin ve Slevin (1991), Stevenson ve Jarillo (1990), Zahra ve Pearce (1994) ve Antoncic ve Hisrich (2001, 2003) şeklinde siralayabilmek mümkündür.

İç girişimcilik ile ilgili yapılan araştırmaların üçüncü ana konusu ise genel olarak yönetimlerin ve yöneticilerin iç girişimciliği teşvik edebilmek için geliştirdiği stratejileri konu almaktadır (Ağca ve Kurt, 2007). Bu alanda araştırmacılar, şirketlerin stratejilerini incelemiş ve neticede yenilikler yapmak suretiyle firmaya rekabetçi avantaj kazandıran iç girişimciliğe odaklanmış yönetim stratejilerini, diğer taraftan da stratejik olarak bu uygulamaları yapan yönetimleri incelemişlerdir. Bu çalışma alanında ayrıca, firma stratejileri ile iç girişimciliğe odaklanmanın nasıl uyum içinde bir arada yürütülebileceğini gösteren çalışmalar da yapılmışıtır. Burgelman (1983), Rule ve Irwen (1988), ve Guth ve Ginsberg (1990) bu alanın önde gelen araştırmacıları olarak sıralanabilmektedir.

\section{4. İç Girişimcilik Kriterleri}

Araştırmalardan ve birçok firma uygulamalarından da anlaşılacağı gibi, firmalar için çok gerekli olan iç girişimciliğin, firmalarda ne ölçüde uygulandığ1 ya da bu kavrama ne ölçüde odaklanıldı̆̆ı ile ilgili yön gösterici olması açısından bazı kriterlerin ortaya konulmasının çok çeşitli yararları olacaktır. Akademi dünyası konuya iki farklı yönden yaklaşmıştır. Bunlardan birincisi, kurumlarda iç girişimciliğe olan yatkınlığ ifade eden ve 'iç girişimcilik eğilimi' olarak adlandırılan araştırma alanını oluşturmaktadır (A ğca \& Kurt, 2007). Bu alanda çalışan belli başlı araştırmacılar ve inceledikleri konular ise; Miller ve Friesen (1983) -yeni ürünler geliştirme, risk alma ve proaktif davranma; Covin ve Slevin (1991) - risk alma, yenilikçilik ve proaktif davranma; Lumpkin ve Dess (1996) - özerklik, rekabetçi girişkenlik, yenilikçilik, risk alma, ve proaktif davranma; Knight (1997) - yenilikçilik ve proaktiflik; Moris ve Kuratko (2002) - yenilikçilik, risk alma ve proaktiflik olarak siralanabilmektedir.

Akademi dünyasının iç girişimcilik kriterleri ile ilgili inceleme yaptuğ ikinci alan ise genel anlamda büyük organizasyonlar seviyesinde konuya yaklaşan ve 'kurum içi girişimcilik' olarak adlandırılan akımdır. Zahra (1991, 1993a, 1995); Guth ve Ginsberg (1990); Stopford ve Baden-Fuller (1994) bu araşturma alanının öncüleri olarak sıralanabilecektir. Antoncic (2000) ve Antoncic ve Hisrich (2003) yapmış oldukları çalışmalarda, iç girişimcilik kriterleri konusuna yapılan iki yaklaşımı birleştirmiş ve tüm araştırmacılar için ortak, anlaşlır bir kriterler listesi oluşturmuşlardır. Buna göre, bu kriterler; yenilik yapma (inovasyon); risk alma; proaktiflik; özerklik (otonomi); yeni iş girişimleri başlatma; kendini yenileme veya stratejik yenilenme; 
ve rekabetçi girişkenlik olarak sıralanmışlardır (Ağca \& Kurt, 2007). Bu kriterlerin birer birer ve iç girişimcilik kavramı ile ilişkileri açısından tanımlanmaları yerinde olacaktır.

Yenilik yapmak (inovasyon): Bu kavram, kendi içinde hem yeniliği meydana çıkarma sürecini hem de ortaya çıkan yenilik sonucunu bir arada ifade edebilmektedir. Yenilik yapmak ile ilgili yapılan araştırmalardaki kavramsal tanımlara örnek olarak Aksoy (2003), yenilik yapmayı; yeni bir fikri pazarlanabilir bir ürüne, ya da bir üretim/dağıtım sürecine, ya da hizmet biçimine dönüştürmek şeklinde tarif etmiştir. Knight (1997) yapmış olduğu çalışmada iç girişimcilikte yeniliği, firmanın yüzleştiği tehditlerde benzersiz çözümler bulabilme gayreti olarak tanımlamıştır. Araştırmacı, bu çözüm önerilerinin, üretim, pazarlama, satıs gibi tüm firma fonksiyonlanında uygulanan yönetim teknikleri ve teknolojileri de içerebileceğini belirtmiştir. Genel anlamda bu kriter ile ilgili araşurma yapan tüm araştırmacıların vardıkları benzer sonuçlarda, firma düzeyinde yapılan yenilikçiliğin, girişimcilik ile ilgili bağlantısında; uygulanan yeniliklerin ister ürün, ister fonksiyon, ister yönetim metotları ya da başka bir konuda ilgili firmalara rekabet karşısında bir avantaj veya bir firsat yarattıklanı sürece, ilgili uygulamanın yenilikçilik ile ilgili başarılı bir hamle teşebbüsü olduğu görüşüne varabilmişlerdir.

Risk almak: Bu kriter, tıpk1 serbest girişimcilikte olduğu gibi iç girişimcilikte de çok önemli ve vazgeçilmez bir kriterdir. Hisrich ve Peters'a (2001) göre; hem serbest hem de iç girişimcilikte makul ölçüde risklerin alınabildiği ve yaklaşımların benzer olduğu vurgulanmıştır. Risk alabilme yani olası gelir ve zararlara katlanabilme özelliği kavramın ilk tanımlandığı yllardan itibaren girişimciliğin temel ilkesi veya kriteri olarak benimsenmiştir (Hisrich \& Peters, 2001; Lumpkin \& Dess, 1996; Antoncic \& Hisrich, 2003). Organizasyonel düzeyde risk alabilme, firmanın kaynaklarının önemli bir bölümünü veya borçlanmak suretiyle pazarda yer alan firsatlara yönelik girişimde bulunmak olarak düşünülmektedir (Ağca ve Kurt, 2007). Yani olası firsatları değerlendirebilmek adına, hızlı davranma, analitik olarak ilgili kaynakları olası firsatlar için kullanabilmek, ve cesur adımlar atabilmek bu anlamda gerekli aksiyonlar olarak kabul edilmektedir. Risk alabilme eğilimi olan firmaların, yeni ürün, hizmet veya pazar alanlarını hedefleyerek, ölçülebilir sınırlar içerisinde çeşitli kereler, göreli olarak düşük riskler alarak denemeler yaptı̆̆ gözlemlenebilecektir (Antoncic \& Hisrich, 2003; Morris \& Kuratko, 2002).

Proaktiflik: Girişimcilik ile ilgili araştırmaların ilk ortaya çıkışından itibaren, bağlı bulunulan pazarda ilk ve öncü olmanın önemi defalarca vurgulanmışır. Bu şekilde öncü ve önder olan firmaların, ilgili pazarlarda önemli firsatları değerlendirdikleri, yüksek gelir elde ettikleri ve özellikle marka konumlandırmada ciddi avantajlara sahip olabildikleri net bir biçimde gözlemlenmektedir (Ağca \& Kurt, 2007). Knight’a (1997) göre, proaktif bir şekilde, özellikle yeniliklerde öncü olma, pazarı analiz edebilme, hızlı ve cesur karşılıklar verebilmek özellikle keskinleşen rekabet dünyasında firmalara önemli avantajlar kazandırabilmektedir. Yapılan bu proaktif davranış tanımlamasını destekler nitelikte Lumpkin ve Dess (1996), proaktif olabilmeyi; gelecekte oluşabilecek sorunlara ve firsatlara karşın önceden tedbir alabilmek ve harekete geçebilmek şeklinde tanımlamışlardır.

Özerklik: Özerklik, bilinen anlamda bir fikri ortaya koymada, uygulamada ve sonuçlannı almada diğer unsurlardan bağımsız olabilmeyi ifade etmektedir. İş dünyası açısıyla bakıldığında, özerklik kavramını stratejik açıdan incelemek yerinde olacaktır. Bu anlamda ürün veya süreçlerin araştırllıp geliştirilmesinden başlayarak, bunlara uygun çözümler geliştirmek özerkliğin ilk adımı olarak düşünülebilecektir (Pinnington \& Haslop, 1995). Devamında; stratejik, yönetsel, ve operasyonel özerklikler ile ilgili kurum açısından oluşturulacak stratejiler ve fonksiyonların işleyişinin iç girişimcilik ile ilgili ilişskisi önemli ve değerlidir (Raelin, 1989). Özerklik açısından diğer bir konu ise, ilgili kurumun yönetim ve organizasyon stratejileridir (Culhane, 2003). Kurumların, gerek organizasyonel şemalarındaki yetki dağllımları ile ilgili, gerek kurumsal iklim ve kültür değerleri açısından, gerekse oluşturulan iş rol tanımlarında inisiyatif kullanımına uygun tanımlar hazırlayabiliyor olması da iç girişimcilik ve özerklik bağlantısı açısından çok değerli olabilecektir.

Yeni iş girişimleri başlatmak: Bu kriteri aslında diğer kriterlerden ayırmak mümkün değildir. İç girişimcilik kapsamında, bu kriter, aksiyon alma ve adım atma kriteri olarak tanımlanmaktadır. Bu kriterin gerçekleșebilmesi için, bundan önce bahsedilen kriterlerin gerçekleştirilebiliyor olması gerekmektedir. Yenilikçilik, proaktiflik, risk alma, ve özerklik kriterleri gerçekleştirildiğinde; yeni iş girişimleri başlatma kriteri için uygun koşullar sağlanmış olmaktadır (Antoncic \& Hisrich, 2003). Bu kriterin gerçekleşmesi ile birlikte firmaların iç girişimcilikten faydalanabileceği stratejik adımları atabilmesi ve sonuçların alınabilmesi 
de mümkün hale gelmektedir. Araştırmanın diğer bölümlerinde de bahsedildiği gibi iç girişimciliğin en önemli unsurları yeni ürün, süreç, yeni iş modelleri oluşturma gibi hamlelerdir ki; bu da 'yeni iş girişimleri başlatmak’ başlığ altında değerlendirilecektir (Stopford \& Baden-Fuller, 1994).

Kendini yenilemek veya stratejik yenilenmek: Bu kriter, akademik araştırmalarda, bazen kurumsal veya organizasyonel değişim kavramı ile benzer kavramlar gibi gözükse de; stratejik yenilenmek, aslında bir ya da birkaç kez yapısal veya diğer bazı alanlarda değil, fakat rekabet karşısında hayatta kalabilmek adına süreklilik gereken bir süreci tanımlamaktadır (Volberda vd., 2001). Temel anlamda sürekli olarak değişiklik gösteren ve çevre ve rekabet koşullarının düzenli olarak yenilendiği günümüz iş dünyasında, firmalar da, organizasyonlarını bu değişime uyumlu hale getirmek zorundadırlar. Bu noktada belirli kereler, kısıtlı süreler veya aksiyonlar dahilinde yapılan 'stratejik değişim' ile süreklilik arz eden ve adeta evrimsel bir süreci tanımlayan 'stratejik yenilenme' kavramlarını birbirlerinden ayırmak gerekmektedir (Huff vd., 1992). Guth ve Ginsberg'e göre (1990); firma düzeyindeki girişimciliği iki farklı alanda incelemek mümkündür. Araştırmacilara göre bunlardan ilki; firma içerisinde yer alan fonksiyonlarda, yeni iş, ürün veya süreçler dahilinde 'yeni iş girişimleri başlatmak' şeklinde olacağı gibi, firmanın kuruluşunda kilit, temel unsurların değiştirilmesi işi ise 'kendini yenilemek veya stratejik yenilenmek' olarak tanımlanabilecektir.

Rekabetçi girişkenlik: Bu kriter, temel anlamda firmanın sadece iç unsurlarına yönelik değil, ancak rakiplerine göre kendini yeniden adapte etmesi gerektiğini ifade etmektedir. Bu girişimcilik kriteri tanımı içerisinde, geleneksel rekabet stratejilerinin yanı sıra; özellikle rakibe odaklanmak, yer yer pazar liderinin, ve rakiplerin zayıf noktalarını hedefleyecek aksiyonlar içine gimek vardır (Lumpkin \& Dess, 1996)

\section{Materyal ve Metot}

Serbest Girişimcilik ve İç Girişimcilik ile İlgili Vaka Çalışması:

Telekomünikasyon Kurumsal ve Bireysel Bayilikleri

$\mathrm{Bu}$ araştırmanın amacı; en eski zamanlardan itibaren var olan girişimcilik kavramının, iş dünyası açısından uyarlanmış tanımlanına uygun olarak sergilenen serbest girişimcilik aktivitelerini ve yine sistem içi yenilik ve ilerlemeyi hedef alan iç girişimcilik aktivitelerini, yaşanmış bir vaka çalışması üzerinden kıyaslamasını yapabilmektir. Araştırmada, bu kiyaslama, hem organizasyonel hem de bireysel açıdan incelenmiş olup, bu iki kavramın benzer ve farklı yönleri ortaya konulmaya çalışılmıştır.

Araştırmada, yöntem olarak vaka çalışması analizi seçilmiştir. Telekomünikasyon gibi sofistike bir pazarda yeni bir firma kuran girişimcilerin, serbest girişimcilik kavramı altında; sürecin devamında, bayiliğini yaptıkları operator firmanın satış ve prim uygulamalarının üzerine kendi geliştirdikleri yöntemler sayesinde önemli ilerlemeler kaydetmeleri ve mevcut düzeni geliştirmek adına yaptıklanı iç ve kurumsal girişimcilik kavramları altında incelenmiş olup yapılan vaka analizinde, girişimciliğin tüm aşamaları, tüm detaylarıyla gösterilmiştir.

Araştırmanın amacına uygun olarak, vaka çalışması analiz edilmeden önce yine literatürde yer alan ve özellikle, serbest girişimcilik ve iç girişimciliğin kıyaslandığ1 çalışmalardan kısaca bahsetmek yerinde olacaktır.

Serbest girişimcilik ve iç girişimcilik kavramlarının tanımsal farklılıkları ile ilgili ilk dönem yapılan akademik çalışmalarda, her iki girişimcilik tipinin de özellikli pazarlar hedeflenerek yapılması gerektiği, aynı zamanda farklılaştırlmış üstün özellikli ürün ve hizmetlerle başarı sağlanacağı ve özellikle pazar segmentasyonunun başarılı sonuçlar doğuracağı belirtilmiştir (Shrader \& Simon, 1997). Yine aynı araştırmalarda, bu taktiklerin iç girişimcilikten ziyade serbest girişimcilikte daha etkili olabileceği belirtilmiştir.

İki girişimcilik tipi, ortaya koyabildikleri performans bakımından da ayıca incelenmiştir. Bu anlamda her koşulda bağlı bulunduğu kurumdaki hiyerarşik yapıya ve diğer bazı kişi, departman veya fonksiyonlara da bağlı olan iç girişimciliğin özerkliği ve dolayısıyla ortaya koyduğu performans ölçütleri, serbest girişimciliğe nazaran tartışmalı bir hale gelmektedir. Hiyerarşik, bürokratik yapılar ve merkezi iş yapış biçimi, iç girişimciliğin önündeki en büyük olası engellerdir diye görüş bildirmek mümkün olabilecektir. Motivasyon anlamında da, girişimciler nezninde, serbest girişimciliğin, iç girişimciliğe kıyasla daha güçlü bir etkinlik alanı oluşturabileceği ortaya konmuştur. Bunun nedeni olarak ise; serbest girişimcilerin yatırım 
yaptıkları sermayeyi kurtarabilmek adına kurdukları girişime yönelik olarak çok daha motive bir şekilde hareket edebilecekleri öngörülmektedir (Ağca \& Yörük, 2006).

Aynı şekilde serbest girişimcilerin, kaynaklara daha zor ulaştı̆̆ düşünülürse, göreli olarak daha fazla kaynağa sahip olduğu düşünülen iç girişimcilere nazaran elde olan kaynaklanı daha iyi kullanabilecekleri ve bu durumun serbest girişimcilerin performanslarını da olumlu bir şekilde etkileyebileceği öngörülmektedir (A ̆gca \& Yörük, 2006).

Shrader ve Simon'a (1997) göre serbest ve iç girişimciliğin arasındaki en dikkat çekici farklar aşağıdaki şekilde özetlenebilmektedir;

- Sermaye bakımından: Sermayeye iç girişimciler, serbest girişimcilere nazaran çok daha zor ulaşmaktadır. İç girişimcilerin sağlayacağı kaynaklar ise bağlı bulundukları kurumlar üzerinden olmaktadir.

- Yönetsel kontrol bakımından: İç girişimciler, kurumların merkezi yapısına bağlı bulundukları için özerklik anlamında çok daha sınırlıdırlar. Serbest girişimciler ise, göreli olarak çok daha özgür oldukları için plan ve aksiyonlarında çok daha hızlı ve esnek olabilmektedirler.

- Yönetimsel motivasyon bakımından: İç girişimciler, göreceli olarak kurum içi birçok dengeyi gözetmekte, ayrıca performansları anlaminda kurumları tarafindan sıklikla değerlendirilmektedirler. Diğer taraftan; serbest girişimciler, ellerindeki sermayeyi koruyabilmek adına hedeflerine çok daha fazla odaklanmış ve çok daha sonuç odaklıdırlar denilebilecektir.

\section{Bulgular}

\subsection{Vakaya Konu Olan ABC Firmasının Iş Girişimi}

Vakaya konu olan girişim; ticari ünvan kullanım kuralları nedeniyle araştırmanın devamında ' $A B C$ firması' olarak adlandırılacaktır. $\mathrm{ABC}$ firmasının bayiliğini yapmış olduğu telekom firması da yine benzer nedenlerle, araştırmanın devamında 'XYZ firması' olarak adlandırılacaktır. ABC firması, iki ortağın kendi sermayeleri ile kurmuş olduğu ve XYZ firmasının 2013-14 yıllarında faaliyet gösteren kurumsal ve iki adet bireysel bayiliklerini yapmak için kurulmuş bir telekomünikasyon firması olarak ticari hayatına başlamıştır. XYZ firması, yeniden yapılanma süreci içinde yapmış olduğu bayilik çeşitleri tanımlamasına ve yapılandırmasına göre yeni girişimciler ararken; $A B C$ firmasının ortakları sahip oldukları tecrübe ve iş bilgisine dayalı olarak XYZ firmasının bayisi olarak ticari operasyonlarına başlamışlardır.

2013-14 yılları süresince, Türkiye telekom pazarında üç tane oyuncu yer almaktaydı ve XYZ firması da bu oyunculardan bir tanesiydi. Firma, kurumsal ve bireysel müşterilerine GSM hatlarını, katma değerli ürünlerini, toplu mesaj hizmetlerini (SMS), cihazları vb. telekom pazarı ile ilgili tüm ürünleri pazarda hedef kitlesiyle buluşturmaya amaçlamıştır. XYZ firması, bahsi geçen dönemde bireysel müşteri pazarında üçüncü sırada yer almakta olup, kurumsal pazarda ise pazar payı olarak ikinci sırada yer almaktaydı. XYZ firmasının ilgili dönemde temel rekabet arac1, rakiplerine göre ürünlerinin en düşük fiyatlara sahip olmasiydi.

ABC’nin üstlenmiş olduğu, merkezi Adana olmak üzere, Adana çevresindeki 9 şehri de içeren bölgede, kurumsal bayilikte; hedef müşteriler, en az 10 çalışan ve en çok 500 çalışan istihdam eden ve genel anlamda KOBİ olarak adlandırlan firmalardı. ABC’nin üstlendiği, XYZ firması bireysel bayilikler kapsamında ise; firma biri Adana diğeri Mersin'de olmak üzere 2 ayrı perakende mağazası işletmiştir. Bu alanda ise hedef müșteri, telekom hizmetlerinden faydalanmak isteyen tüm bireysel müşteriler olarak belirlenmiştir.

ABC firmasının gelirlerinin önemli bir bölümü, XYZ tarafından sağlanmaktaydı. Buna göre, ABC firmas1; öncelikle satılan mobil hat adetinden, daha sonra sattğg hatların ürettiğgi fatura tutarından, ve son olarak satılan katma değerli ürünlerden farklı kriterlere göre XYZ firmasından prim almaktaydı. ABC firmas1, cep telefonu veya diğer cihazların üretici firmalarından ise ayrıca primlendirilmekteydi.

ABC firması, operasyon yaptığı alanlar kapsamında; kurumsal satış temsilcileri, bireysel satış temsilcileri, her iki operasyon alanında birim yöneticileri, müşteri şikayetleri ile ilgilenen ve tarife bitişlerini yapan aktivasyon ekibi, müşterileri arayıp satış yapmaya çalışan tele-satış ekibi, muhasebe personeli, ve insan kaynakları personeli istihdam etmiştir. Bunun yanı sıra iki farklı şehirde, tüm çalışanlar için ofisler, kurumsal satış ekibi için şirket araçları, mağazalarda yer alan aksesuar ve telekom cihazlanı da firmanın varlıkları arasında yer almıştır. ABC firması, operasyonlarını sürdürdüğü iki senelik süreçte, 45-50 kişilik 
istihdama ulaşmıştır. Bunun yanı sıra 17-18 araçlık filoya sahip olmuştur. Bu araçların bir bölümü firmanın varlıkları kapsamında satın alınan araçlar, diğer bir kısmı ise filo kiralama firmalanı aracılığı ile kiralanmış araçlar olarak kullanılmaktaydı.

ABC firması, operasyonlarını bitirdiği dönem itibarıyla, ilgili dönemin döviz kurlan üzerinden yılllk yaklaşık bir milyon dolar ciroya ulaşmıştı. ABC firması, operasyonlarını sonlandırdığı dönemde; XYZ firmasının bayileri içinde, hedef gerçekleştirme ve net kazanç olarak en başarllı bayisi, toplam satış rakamlarında ise Türkiye'nin en başarılı üçüncü bayisi konumundaydı.

\subsection{ABC Firmasının İç Girişimciliği}

Yukanda belirtildiği üzere, ABC firmasının gelirlerinin önemli bir kısmı, XYZ firmasının belirli koşullara dayalı olarak verdiği prim başarı sistemlerine uygun hedeflere ulaşılması durumunda kademeli olarak sağlanmaktaydı. Bu prim sistemi içerisinde, XYZ firmasının dönemsel stratejilerine uygun olarak yine dönemsel bazı değişiklikler olsa da genel anlamda öncelikle satılan mobil hat, katma değerli ürün veya cihaz satış adetine, daha sonra da bu ürünlerin satıldığı müşterilerin üretmekte olduğu fatura miktarlarının belirli bir bölümünü içerecek şekilde iki ana başlı̆̆ı içermekteydi.

Diğer yandan XYZ firmasının, ABC firması da dahil olmak üzere bayilerine uygulamakta olduğu cezalar da mevcuttu. Buna göre, satlan hatlar ve kullanımları belirli sürelerden önce sonlanırsa, veya ürün satılan müşteriler gerçek değil fakat muvazzalıysa, ya da tahüt ettikleri ödemelere sadık kalmayıp ödemeleri keserlerse ABC firması da oluşan koşula göre belirli oranlarda cezalar ödemek durumundaydı.

XYZ firması, ABC firması da dahil olmak üzere, her bayilik tipinde kaç çalışan olması gerektiği ve bu çalışanların iş tanımları ile ilgili katı kurallar dikte etmekteydi. Bunun yanı sıra XYZ firmasının, bayi çalşsanlarına yönelik olarak hiçbir İnsan Kaynakları uygulaması bulunmamaktaydı. Yine XYZ firmasının bayilerine ve yerel olarak bayi bölgelerindeki müşteri hedef kitlesine uygun olarak hiçbir özel pazarlama çalışması veya desteği bulunmamaktaydı, bunun yerine Türkiye çapında sürdürmekte olduğu genel pazarlama çalışmalarını ve kitle reklam unsurlarını tüm bayileri için yeterli bulmaktaydı. XYZ firmasının tüm Türkiye'deki bayilerine yönelik olarak bir 'Müşteri Yönetimi Sistemi' vardı, ancak bu sistem sadece satış yapılan müşterilerin iletişim bilgilerini ve satılan ürün(ler) ile ilgili detaylant arşivlemek için kullanılan bir sistemdi. Ancak bu sistem, geleceğe yönelik olarak, gerek yeni müşteriler gerekse mevcut müşterilere yapılacak olan olası yeni satışlar ile ilgili herhangi bir veri içermemekteydi. Son olarak XYZ firmasının, satış sahasını etkili ve verimli kullanmaya yönelik herhangi bir programı yoktu; bayilerinin saha satş temsilcilerinden sadece günlük belirli adette müşteri ziyaretinin tamamlanmasını istiyor ve denetliyordu.

ABC firması ortaklanı, sahip oldukları tecrübelerden ötürü sadece serbest girişimcilik yapmayıp aynı zamanda daha verimli bir firma yönetebilmek adına iç girişimcilik örneği de sergilemişler ve XYZ firmasının, bayileri için öngördüğü operasyonel sistemde bazı değişiklikler yapmışlardır. Yani aynı operasyonel sistem içerisinde, farklı sonuçları elde edebilmek için çerçevenin dışına çıkıp birçok yeni uygulamayı ve yeni yöntemi hayata geçirmişlerdir. Bu değişiklikleri temel olarak iki başlık altında düşünmek yanlış olmayacaktır. Bunlardan birincisi operasyonel ve işin yürütülme sürecine yönelik uygulamalar olarak kabul edilebilecekken, diğer başlık ise insan kaynaklanı yönetimi başlğı altında incelenebilecektir.

Operasyonel anlamda $A B C$ firması, XYZ firmasının, $A B C$ çalışanları için tasarlamış olduğu ve uygulanmasını zorunluğu kıldığı prim sistemi ile yetinmemiştir. Firmanın ortakları, kişisel kazançlarının bir bölümü ile çalışanlara ek prim sistemi tasarlamış ve ilgili prim tutarları ile kendi çalışanlarını Türkiye çapında yer alan tüm bayi çalışanlarından daha fazla kazanan bir pozisyona sokmuştur. Bu prim sisteminde özellikle, yapılan hat ve diğer ürün satışlarının gerçek olmasını, faturalarının ödenmesini ve müşteriler tarafından yüksek faturalar ödenmesinin sağlanması için ABC firmasının ortakları zamana yayılan ve firma kazandıkça personelin de kazanacağı bir prim sistemi oluşturmuşlar ve bu primi kendi kazançlarından sağlamışlardır. Bunun yanı sıra firma ortakları; normal şartlarda XYZ firmasının öngördüğü gibi, sadece belirlenen pozisyonlara belirlenen prim tutarlarının ödenmesi ile yetinmemiş, firmanın çeyrek bazlı olarak elde ettiği net gelir tutarları üzerinden firmanın tüm çalışanlarına, katkı payları oranında yine ayrıca prim ödemesi yapmışlardır. Bu iki uygulama, $\mathrm{ABC}$ firmasının orta ve uzun vadede asgari ceza yemesini, tüm çalışanların sadakatla firma içinde çalışmasını ve firmaya duydukları aidiyet ve sevginin azami düzeye çıkmasını, firmanın tüm birimlerinin genel amaçlar doğrultusunda çalışmasını ve takım olma olgusunu 
beraberinde getirmiştir. $\mathrm{Bu}$ sistemle birlikte $\mathrm{ABC}$ firması, XYZ firmasının, ürün satışlarının ardından yaptığ1 takipler sonucunda kesebileceği olası cezalardan da azami bir şekilde kurtulmuştur.

Operasyonel süreçler anlamında $\mathrm{ABC}$ firmasının, uygulamış olduğu diğer bir iç girişimcilik hamlesi ise saha satış temsilcilerinin sahayı kapsama biçimiydi. Önceden de belirtildiği gibi; XYZ firmasının bayilerinin satış temsilcilerinden beklediği günlük bir müşteri ziyareti sayısı vardı ve bunun dışında herhangi bir insiyatif konmamışt. ABC firma ortakları, sahadaki mevcut ve potansiyel müşterilerini; potansiyelleri, geçmiş projeleri, mobil ürün alma potansiyelleri, mevcut projeleri vb. bazı faktörlere bakarak, istihdam ettiği saha personeli için farklı ziyaret sıklıkları belirlenmiş, ziyaret programlanı hazırlamış ve buna göre müşteriler ile odaklı bir biçimde ilgilenilmiştir. Bu ABC firması için sahadan alınan verimliliği ve etkinliği, dolayısıyla sonuçları olumlu yönde önemli ölçüde etkilemiştir.

Önceki bölümlerde de belirtildiği gibi, XYZ firmasının Türkiye çapında kullanmakta olduğu bir 'Müşteri Yönetimi Sistemi' mevcuttu ve bu sistemi Türkiye çapinda XYZ'nin anlaşmalı olduğu ve sahada olan tüm bayileri kullanmaktaydı. Ancak bu sistem, sadece satıs yapılan müşterileri ve aldıklanı ürünleri kaydetmeye aracillk yapiyor, fakat bunun ötesinde herhangi bir kayıt bulundurmamaktaydı. ABC firmasi ortakları, yine kendi bütçeleriyle ve XYZ firmasından destek almadan, bir yazılım firması ile bir algoritma oluşturmuş ve kendi saha personelinin kullanımı için bu yeni yazılım sistemini ortaya koymuştur. $\mathrm{Bu}$ sistem; $A B C$ saha satış temsilcileri ziyaret ettikleri müşterilerin tüm iletişim bilgilerini, geçmiş satışlarını, doğru kontak kişileri ve bu kişilerle ilgili kişisel bilgileri, ziyaret edilen müşterinin iş kolunu, mevcut projelerini, olası projelerini, mobil ürün kullanım potansiyellerini vb. birçok ek bilgiyi kaydetmelerine imkan vermiş ve bu sayede ilgili yazılımın, $A B C$ ’nin tüm stratejilerini kurgulama şansını vermiştir. Bu da ABC'nin yine iç girişimcilik yaparak, yenilikler konusunda inisiyatif kullanmasını ve bu hamleden ciddi kazanımlar sağlamasını temin etmiştir.

ABC firmasının, operasyonel süreçlerle ilgili yaptığ diğer bir iç girişimcilik hamlesi ise pazarlama fonksiyonu ile ilgiliydi. Önceden de belirtildiği üzere XYZ firması sadece ulusal ölçekte pazarlama aktivitelerini sürdürmekteydi. Müşteri segmentasyonu, bireysel müşteriler bazında uygulanıyor olup kurumsal bazda ise çok ender yapılan kitle medya iletişim ve reklamları hariç herhangi bir uygulama yapılmamaktaydı. ABC firması, inisiyatif kullanıp ilgili segmentasyonu kurumsal müşterileri için de mikro düzeyde ve kendi sorumlu olduğu alan içerisinde uygulamışır. Kurumsal müşterilerinin iş kolları, alım sıklıkları, kaç farklı ürün grubundan alım yaptıklarına göre müşteri segmentasyonu yapıp ilgili müşteri segmentlerine göre pazarlama argümanlarını kullanmış ve kaynak kullanım ve dağılımını bu sınıflandırmalara göre yapmıştır. Bunun yanı sıra ABC firması, yine pazarlama kapsamında bölgesel / yerel bazı sektörel dergilerde reklam vermiş, hizmetlerini haber yaptırmış ve bazı fuarlara katılım göstermiştir. Bahsedilen bu aktivitelerin masraflarını, $\mathrm{ABC}$ firmasının ortakları, yine kendi bütçelerinden karşılamışlardır. Tüm bu etkinlikler neticesinde; $A B C$ firmasının ortaklarının kullandığı inisiyatif ve iç girişimcilik hamleleri sonucunda önemli satış ve gelir artş̧ları sağlanmıştır.

ABC firması ortakları, önceki bölümde de belirtildiği gibi, iç girişimcilik hamleleri olarak sadece operasyonel süreçlerde değil, aynı zamanda 'İnsan Kaynakları Yönetimi' anlamında da çeşitli hamleler gerçekleştirmiştir. Öncelikle XYZ firması için departmanlar ve tüm çalş̧anlar aynı seviyedeyken, tek bir bayi müdürü talep eden ve sadece gerekli olan departman başına çalışan adetleri belirlenmişken, $A B C$ firması ara yönetici pozisyonu kavramını türetmiş ve her departman başına 'Departman Müdürü' pozisyonu oluşturmuş̧tur. Bu iç girişimcilik hamlesi, sadece yönetimsel olarak daha sade, yönetilebilir ve etkili bir operasyon akışı sağlamamış, aynı zamanda firma içi çalışanlara inisiyatif kullanarak yeni bir ara hedef oluşturmuştur. Bu sayede, ABC firmasının farklı departmanlarındaki her çalışanı hale hazırda kazanabileceği prim haricinde, aynı zamanda daha iyi koşullara sahip olabileceği ve yönetici ünvanı kazanabileceği yeni bir hedefe de kavuşmuştur. Bu da her çalışanın işini daha dikkatli, hırsl, ve verimli yapma güdülenmesi oluşturmuştur.

Bunların yanı sıra, $\mathrm{ABC}$ firması ortakları, normal bayilik çalışma prensipleri içinde olmamasına rağmen, XYZ firması ile müzakereler yürütmüş ve her sene en az 1 çalışanının, performans kriterlerinin tutması halinde, XYZ çalışanı olmasını kabul ettirmiştir. Bu ABC çalışanları için, ayrıca bir motivasyon unsuru haline gelmiştir, ve bu sayede yaptığı işleri ileride bir bayi personeli olarak kalmaktansa, Türkiye çapında bir telekom firmasının çalışanı olabilmek adına çok daha etkili ve dikkatli yapmaları için bir firsat sunmuştur. 
'İnsan Kaynakları Yönetimi’ başlığı altında, ABC firması ortaklarının son hamlesi ise; tüm firma çalışanlarını bir arada ve ekip ruhunu geliştirecek yemek, etkinlik vb. aktiviteleri düzenlemesinin yanı sıra bazı ara hedefler doğrultusunda çalışanlarına, eşleriyle birlikte vakit geçirecekleri, tatil, akşam yemeği gibi özel bazı ödüllere de yer vermek olmuştur.

Tüm bu operasyonel ve İK Yönetimi uygulamaları; ABC firması ortaklarının, XYZ firmasının, bayileri için tasarladıkları sistemin dışında oluşturulmuş olup, kendi sermayelerinden risk alarak ek ödemeler yaptıklanı, mevcut iş yapış sistemlerine göre inisiyatif kullanıp birçok yenilik getirdikleri ve bu aktivitelerden çok olumlu ve etkili sonuçlar aldıkları iç girişimcilik hamleleri olarak kayda geçmiştir.

\subsection{ABC Firmasının Serbest Girişimcilik ve İç Girişimcilik Karşılaştırması}

Örnek olarak incelenen vaka çalışmasından net bir şekilde görülebileceği gibi, ABC firması ticari iştirakı; hem serbest girişimciliğin hem de iç girişimciliğin aynı anda gözlemlendiği ender örneklerden biri haline gelmiştir. Öncelikle ilgili vaka çalışmasının, her iki girişimcilik aktivitesini içerdiği ve bu anlamda birbirlerine benzer özellikler gösterdiği alanları incelemek yerinde olacaktır.

Vaka çalışmasında her iki girişimciliği gerçekleştiren kişiler, ABC firmasının ortakları, aynı kişiler olduğundan her iki girişimcilikte de gösterilen girişimci profil, karakter özelliklerinin de aynı olması kaçınılmaz olmuştur. Araştırmanın ilk bölümünde yer alan ve başarılı girișimcilerin ve aynı zamanda iç girişimcilerin sahip olması gereken profil özelliklerinin, $A B C$ firmasının iki ortağında da olduğu düşünülmekte ve bu sayede her iki girişim hamlesini de başarabildikleri düşünülmektedir. Yine illk bölümde belirtilen, girişimci özelliklerinin teknik, yönetsel, ve bireysel becerileri içermesi gerektiği olgusu; $A B C$ firmasının ortaklarının hem ABC'yi kurma aşamasında hem de anlatılan iç girişimcilik hamlelerinde farklı birçok örnekle gerçekleştiği gözlemlenebilmiştir. Yine önceki bölümlerde belirtilen iç girişimcilik kriterlerinin; yenilik yapmak, risk almak, proaktif olmak, özerklik, yeni iş girişimleri başlatmak, stratejik yenilenme, rekabetçi girişimcilik aynı şekilde serbest girişimcilikte de çok gerekli ve değerli oldukları hem genel örneklerden hem de araştırmaya konu olan vaka çalışmasındaki süreçlerden gözlemleyebilmek yadsınamaz bir gerçekliktir.

$\mathrm{Bu}$ noktada serbest girişimcilik ve iç girişimcilik kavramlarının tamamen aynı kavramları ifade edip etmedikleri analizini, araştırmaya konu olan vaka çalışması üzerinden irdelemek yerinde olacaktır. Öncelikle iki farklı tip girişimcilik kavramı arasındaki fark, kavramların tanımları üzerinden başlamaktadır. Önceki bölümlerde de farklı tanımlarla açıklandığı gibi özet anlamda 'serbest girişimcilik'; yeni organizasyonarı kurma fikrini ortaya koyarken; 'iç girişimcilik' ise, hale hazırda operasyonlarını sürdüren organizasyonlarda gerçekleştirilen girişimcilik aktiviteleri olarak tanımlanmaktadır (Antoncic \& Hisrich, 2003). Araştırmaya konu olan vaka çalışmasında da; ABC firmasının kuruluşu serbest girişimcilik olarak incelenirken, firma ortaklarının ortaya koyduklan yenilikler ise iç girşimcilik başlı̆̆ı altında incelenmiştir.

Luchsinger ve Bagby (1987); her ne kadar serbest ve iç girişimcilik kavramlarını birbirlerine benzetmiş olsalarda, iki kavramın gerçekleştirildiği koşullar noktasında farklılıklar olduğunu ortaya koymuşlardır. Araştırmacılara göre; bu farklılığın, kaynaklara erişim ve strateji-yapı-performans ilişskileri bakımından ortaya çıktı̆̆ belirtilmiştir. Bu sonuçlara çok benzer olarak Shrader ve Simon (1997), serbest ve iç girişimcilik farklarını inceledikleri uygulamalı araştırmada, 'kaynaklar', 'uygulanan stratejiler' ve 'finansal performans seviyesi' olarak farklılıkları üç başlık altında toplamışlardır. Kaynaklar ile kastedilen, organizasyonun ve/veya iç girişimcinin amaçlarına ulaşabilmek adına kullanabildikleri tüm kaynaklar olarak tanımlanırken, araştırmacılara göre bunları; fiziksel, finansal, organizasyonel, ve teknolojik olarak gruplayabilmek mümkündür.

Kaynakların temin edilmesi her iki girişimcilik aktivitesinde de çok önemlidir ancak bu kaynakların nasıl elde edileceği iki girişimcilik tipi arasındaki farklardan bir tanesini meydana getirmektedir (Ağca \& Yörük, 2006). Çok açık bir şekilde serbest girişimcilikte; sermaye, büyük riskler alınarak, girişimcilerin kendi sermayelerinden veya banka ya da fon gibi finansal kuruluşlardan karşılanırken, iç girişimcilikte gerekli olan kaynaklar bağlı bulunulan organizasyonlardan sağlanabilmektedir. İlgili kaynaklar, sadece bağlı bulunulan kurumun finansal veya iç kaynaklarından değil, aynı zamanda yine bağlı bulunulan kurumun kurumsal markasına dayanarak dış kaynaklardan da sağlanabilmektedir. Dolayısıyla kaynakların temini noktasında, 
açık bir şekilde iç girişimcilik sürecinde, serbest girişimciliğe nazaran kaynaklar çok daha kolay ve çok daha az bir riskle elde edilebilmektedir.

$\mathrm{Bu}$ araştırmaya konu olan vaka çalış̧masında da bu ayrım çok net bir şekilde gözlemlenebilmektedir. $\mathrm{ABC}$ firması ortaklanının, firmalarını kurarken aldıkları risk geri dönülemez ve kendi sermayeleri ile gerçekleşmişken, firma ortaklarının iç girişimcilik boyutunda daha başarılı olabilmek ve daha çok gelir elde edebilmek için yaptıkları aktiviteler için gerekli olan kaynaklar ise göreceli olarak çok daha düşük miktarda, vazgeçilebilir ve firmanın devamlılığına zarar verme ihtimali olmadan temin edilebilmiştir.

\section{Tartışma ve Sonuç}

Araştırmada; öncelikle girişimciliğin tarihçesi ve tanımlanması, akademisyen ve araştırmacılar tarafindan konuya yönelik farklı yaklaşımlar ışığında incelenmiş, daha sonra aynı süreçler iç girişimcilik kavramı için de ortaya konmuştur. Araştırmanın amacı olan serbest ve iç girişimcilik mukayesesi, literatürde daha önce yapılmış çalışmalardan bazı örnekler de gösterilerek, açıkça ortaya koyulmuştur; ayrıca araştırmanın yöntemi olan vaka analizi ile ilgili genel bir tanım yapılmıştır. Araştırmanın devamında, araştırmaya konu olan vaka çalışmasında; Türkiye telekomünikasyon sektöründe yer almış olan bir firmanın, sektörün üç büyük operatörlerinden birinin bayisi olarak ticari hayatına başlangıcını ve operasyonlan incelenmiş ve ayrıca firma ortaklarının operasyonlar devam ederken tasarladıkları ve uyguladıkları iç girişimcilik aktiviteleri detaylarıyla anlatılmış ve sonuçları ile ilgili bilgiler verilmiştir. Araştırmanın takip eden bölümünde ise; araştırmaya konu olan vaka çalışması üzerinden uygulanan serbest ve iç girişimcilik aktiviteleri ve bu iki kavrama ait özelliklerin benzer ve farklı yanları incelemeye konu alınmıştır.

Genel anlamda serbest girişimciliğin de, iç girişimciliğin de ekonomik düzen açısından çok yararlı olduğu söylenebilecektir. Başarıyla gerçekleşen serbest girişimcilik örnekleri; makro ekonomik dengeler açısından, ortaya çıkan üretim, istihdam, vergi, vb. diğer unsurlar ile birlikte önemli pozitif katkılar oluşturmaktadır. Benzer bir biçimde, başarılı iç girişimcilik örnekleri ise; mevcut kurumların daha ileri gitmesini, daha çok kazanmasını, rekabetin gelişmesini, dolayısıyla yine daha çok vergi, istihdam vb. avantajlar yarattı̆g gibi rekabete yaptığı katkı sayesinde de genel anlamda var olduğu sektörleri olumlu anlamda geliştirebilmektedir.

$\mathrm{Bu}$ çalışmada, öncelikle araştırmaya konu olan vaka çalışmasında, $\mathrm{ABC}$ firmasının ortaklarının kendi sermayeleri ile kurmuş oldukları ve serbest girişimcilik örneği sergiledikleri ticari girişimlerinin, akademik literatürün serbest girişimcilik ile ilgili tanımlanmış özellikleri sergileyip sergilemedikleri sorgulanmıstır. $\mathrm{Bu}$ incelemede; $\mathrm{ABC}$ firmasının ortaklarının, gerek sahip oldukları karakter veya profil özelliklerinin gerekse teknik veya yönetsel becerilerinin, akademik araştırmalarda, başarılı girişimcilik için gerekli olduğu öngörülen özelliklerin bir çoğuna sahip oldukları ve bu özelliklerini kullanabildikleri gerçek bir örnek üzerinden ortaya konabilmiştir.

Diğer yandan, aynı vaka örneğinde yine gerçek bir örnek üzerinden iç girişimciliğin süreçlerini gözlemleyebilmek ve akademik araştırmalarda iç girişimcilik için gerekli olan kişi profil özellikleri ve süreçlerin de nasıl gerçekle uyuştuğu ortaya koyulabilmiştir. Bunlardan daha önemlisi, yaşanmış bir vaka çalşşması üzerinden serbest girişimcilik ile iç girişimcilik kavramları mukayese edilmiştir. Araşıırmaya konu olan vaka çalışmasında çok açık bir şekilde her iki girişimciliğin, girişimcilerin karakter özellikleri gereksinimi olarak birbirlerine ne kadar çok benzediği ve yine gerekli olan profil özelliklerinin her iki girişimcilik aktivitelerini de başarıya götürebildiği ortaya konmuştur.

İki girişimcilik tipi arasındaki en belirgin fark ise, girişimcilerin kaynakları nasıl elde ettiği ve nasıl kullanabildikleri ile ilgilidir. Araştırmada yer alan vaka çalışmasında da, ABC firmasının ortaklanı, firmalarını kurarken kendi sermayelerini kullanmıs, dolayısıyla önemli bir risk almışlar ancak buna karşılık iç girişimcilik olarak hale hazırda kazanmakta oldukları gelirden, inisiyatif kullanarak bazı aktiviteleri uygulamışlardır. Bu anlamda firmayı kurarken almış oldukları risk, onların çok daha detaylı, derin, kapsamlı ve entegre planlarını uygulamalarını sağlamış, fakat diğer yandan iç girişimcilik adına planladıkları aktiviteleri tek hamlelik, geri dönülebilir ve kısmi kazanımları elde etmek üzerine tasarlanmış ve uygulanmıştır. Aynı şekilde firma ortaklarının, firmayı sürdürülebilir kılmak adına sahip oldukları motivasyon, iç girişimcilik aktivitelerindeki istek ve güdülenmeye nazaran çok daha kuvvetli ve etkin olmuştur. Diğger yandan, ABC firmasının ortaklanı, firmalarını kurarken sadece XYZ firmasını ikna etmiş 
ve bir çerçeve doğrultusunda ekiplerini belirlerken, bunun dışında tüm kararlarında özgür davranmışlardır. Ancak almış oldukları iç girişimcilik inisiyatiflerinin her adımında, XYZ firmasının onayını almak ve sonuçlarını yine XYZ firmasının yetkilileri ile paylaşmak durumunda kalmıs ve ancak onay alabildikleri adımlarda ilgili aktivitelerine devam edebilmişlerdir, yani kısmi olarak özgür olabilmişlerdir.

Araştırmayı kuvvetli yapan taraflardan ilki; gerçek bir vaka çalışmasını konu etmesi ve bu nedenle gerek kavramların tanımlanmasına yönelik gerekse iki girişimcilik tipinin benzer ve farklı yönlerinin irdelenmesinde teorik araştırmalann çok daha net bir şekilde ortaya koyulabilme özelliğidir. Araştırmanın diğer bir kuvvetli özelliği ise; serbest girişimcilik ve iç girişimcilik aktivitelerini planlayan ve uygulayan kişilerin, aynı kişiler olması ve bu nedenle özellikle profil özellikleri bakımından iki farklı türdeki gereksinimlerin çok daha sağılkı bir şekilde kıyaslanabilir olmasıdır. Araştırmanın üçüncü kuvvetli yanı ise, hem serbest hem de iç girişimcilik süreçlerinin, tanımlarına uygun bir şekilde, uygun koşullar ve süreçlerin de oluşumuyla net bir şekilde gözlemlenebilir olması, bu nedenle de ilgili analizlerin çok sağlıklı bir şekilde yapılabilir olmasıdır.

Araştırmanın, serbest girişimcilik ve iç girişimcilik açısından gerçek bir vaka çalışmasını konu almasından ötürü akademik çalışmalar açısından anlamlı olabileceği düşünülmektedir. Bundan sonra yapılacak araştırmalarda, her iki girişimcilik ile ilgili kişi profillerinin ve iş süreçlerinin daha belirgin ve daha somut biçimlerde ortaya konabilmesi ve bu kriterler üzerinden yapılacak sayısal araştırmalar, araştırma alanı için çok değerli olabilecektir. Devam edecek olan araştırmalarda; ayrıca gerek makro düzeyde ülke ekonomisi ve yöneticilerinin gerekse mikro düzeyde firma yöneticilerinin, girişimcilik olgusunun ortaya çıkabilmesi için hazırlaması gereken uygun koşulların neler olabileceğini belirleyen çalışmalar yapabilmek çok anlamlı olabilecektir. Bunun yanında, araştırmaya konu olan vaka çalışmasında da olduğu gibi, serbest ve iç girişimciliğin bir arada incelenebildiği örnekler için yine sayısal olarak bağıntıların ortaya konabildiği araştırmalarda çok anlamlı olabilecektir. Devam edecek olan araştırmalarda, araştırmanın farklı kültür ögelerinin baskın olduğu başka ülke pazarlarında ve/veya yine sektörel etkilerin varllğını ya da etkisini anlayabilmek adına telekom sektörü dışındaki sektörlerde tekrarlanıyor olması da farklı sonuçları ortaya ç1karabilecektir.

Araştırmanın daha etkili olabileceği diğer bir alan ise iş dünyasıdır. Araştırmanın önceki bölümlerinde de bahsedildiği gibi gerek serbest girişimcilik gerekse iç girişimciliğin, girişimciliğin gerçekleştirildiği ülke pazarının hem makro hem de mikroekonomisine pozitif anlamda önemli bir ölçüde katkı yaptı̆̆1 düşünülmektedir. Bu araştırma, bir kez daha göstermiştir ki, öncelikle makro düzeyde ülkelerin, girişimcilik faaliyetlerinin artması ve gelişmesi için her türlü programı tasarlaması gerektiği gibi, mikro düzeyde de firmaların, bünyelerinde daha fazla iç girişimci istihdam etmesi ve iç girişimcilik süreçlerinin artması için çaba göstermesi gerekmektedir. Bununla ilgili olarak firmalar, çalışanlarının işe giriş süreçlerinden başlamak kaydıyla ve doğru mülakat teknikleri ile girişimci profiline uygun çalşsanları istihdam etmek durumundadırlar. Daha sonra, ilgili çalışanların girişimcilik aktivitelerini yapabilmesi için uygun firma iklim, kültürünün yerleştirilmesi ve operasyonel anlamda ve hiyerarşik yapıda da gerekli tasarımların ve uygulamaların yapilması yerinde olabilecektir.

Firmalar girişimcilik aktivitelerini desteklemek adına, ayııca çalışanlarının daha çok risk aldıkları ve daha motive ve dikkatli bir şekilde düzenledikleri aktivitelerini sonuçlandıracak bir biçimde kurumsal yapı ve süreçleri de oluşturmak ya da yeniden yapılandırmak durumundadırlar. Son olarak firmaların, bünyelerinde istihdam ettikleri iç girişimcileri, dış operasyonlarında kullanmak ve ilgili kişileri tüzel birer yapı haline dönüştürüp operasyonlarında onlar ile birlikte çalışmak fikri de ayrıca çok etkili olabilecektir.

\section{Extended Abstract}

The purpose of the study is; to explain the details of the free entrepreneurship concept, that started with the beginning of the human life, to explain the activities relevant with the entrepreneurship, to explain the intrapreneurship concept, that mainly targets the development and the improvement processes in an existing system, and finally to compare those two different entrepreneurship concepts with a case study analysis by highlighting all the similarities and the differences between them. In the research, the comparison in between those two different entrepreneurship types is analyzed both from the corporate perspective and from the individual perspective. 
In this research, case study analysis is chosen as the methodology of the study. In the case study, a company is subjected which was founded by two entrepreneurs and operated in Turkish telecommunication industry which has very sophisticated features. The company started to operate as the 'Small and Medium Enterprises Dealer - SME Dealer' and as the 'Customer Product and Services Dealer' with its two retail shops located in two different cities of one of the three telecommunication operators positioned in Turkish market. The foundation and the operational activities of the company are correlated with the free entrepreneurship concept. In addition, the strategies and the applications of the founders of the company with all the details, subjected in the case study, that challenge the existing strategies and the applications of the main telecommunicatiton operator company so called as intrapreneurship activities are correlated with the intrapreneurship concept. After explaining the company's free entrepreneurship and intrapreneurship activities then a comparison is made in between two different entrepreneurship activities with all the similarities and the differences of those two.

This research, which compares the entreprenurship and intrapreneurship concepts and studies a real case study composes of two sections. In the first section; the different definitions and the historical development of the entrepreneurship concept are studied at variable academic researchs continued with the potential benefits and the effects of the entrepreneurship concept to the business world is mentioned. It continues with the introduction of the case study at which the foundation of a new company is subjected that shows the basic expression of free entrepreneurship. In the research; the profile and characteristic features of the entrepreneurs, which is the most important factor of the entrepreneurship, are analyzed. In addition, the necessary requirements for entrepreneurs in terms of their professional vision; in terms of their technical and operational perspectives; and in terms of their leadership features are shown with the support of academic researchs done before on those specific subjects. As a result, the reflections of the features of the entrepreneurs and generally the entrepreneurship concept in the business world and corporate life is tried to be explained, again with the support of variable academic researchs done before.

In the second part of the first section; a comperatively new concept, 'intrapreneurship' concept is tackled. The variable definitions of the 'intrapreneurship' concept, which is basically defined by the efforts to sustain innovation and development in an existing system, are explained with all the historical milestones and its corporate effects. In addition, the criteria set for being an intrapreneur is also explained.

In the second section of the research, the case study subjected at this research is explained. Firstly, the environmental conditions, the motives and the requirements of the company founders and all the processes realized during the life of the company are explained. In addition, the relation in between the foundation of the company and the free entrepreneurship concept is analyzed. Afterwards, the strategy and all the applications company founders made to develop and to improve all the processes instructed by the main telecommunication operator company are explained on behalf of the intrapreneurship concept. In the final part of the second section, both the similarities and the differences in between free entrepreneurship and intrapreneurship is analyzed by focusing on the company processes placed in the case study.

\section{Kaynakça}

Ağca, V. ve Yörük, D. (2006). Bağımsız Girişimcilik ve İç Girişimcilik Arasındaki Farklar: Kavramsal bir Çerçeve. Afyon Kocatepe Üniversitesi, I.I.I.B.F. Dergisi, C.VIII (2), 155-173.

Ağca, V. ve Kurt, M. (2007). İç Girişimcilik ve Temel Belirleyicileri: Kavramsal Bir Çerçeve. Erciyes Üniversitesi İktisadi ve İdari Bilimler Fakültesi Dergisi, 29 (Temmuz-Aralık), 83-112.

Antoncic, B. ve Hisrich, R.D. (2003). Clarifying The Intrapreneurship Concept. Journal of Small Business and Enterprise Development, 10 (1), 7-24.

Antoncic, B. ve Hisrich, R. D. (2001). Intrapreneurship: Construct Refinement and Cross-Cultural Validation. Journal of Business Venturing, 16 (5). 495-527.

Antoncic, B. (2000). Intrapreneurship: Construct Refinement and An Integrative Model Development. Thesis for The Degree of Doctor of Philosophy. Department of Marketing and Policy Studies Weatherhead School of Management, School of Graduate Studies, Case Western Reserve University. 
Aksoy, M. (2003). Firma Düzeyinde Yenilik ve Bilgi Yönetimi. KalDer Forum, 3 (12). 17-22.

Arıkan, S. (2002). Girisimcilik. Ankara: Siyasal Kitabevi.

Bozgeyik, A. (2005). Kri₹ Dönemlerinde Girişimcilik Neden Daba Önemli? www.bilgiyonetimi.org/cm/pages/mkl_gos.php?nt=577. [Erişim: 10 Şubat 2019].

Burgelman, R. A. (1983). A Process Model of Internal Corporate Venturing in The Diversified Major Firm. Administrative Science Quarterly, 28 (2). 223-244.

Burgelman, R. A. (1985). Managing The New Venture Division. Research Findings and Implications for Strategic Management. Strategic Management Journal, 6 (1). 39-54.

Carbone, T. C. (1986). The Making of A Maverick. Management World, 15 (5). 13-16.

Carrier, C. (1996). Intrapreneurship In Small Businesses: An Exploratory Study. Entrpreneurship Theory and Practice, 21 (1). 5-20.

Coulter, M. ve Robbins, P.S. (2003). Management. New Jersey: Prentice Hall, 7. Bask1.

Covin, J. G. ve Miles, M. P. (1999). Corporate Entrepreneurship and Pursuit of Competitive Advantage. Entrepreneurship Theory and Practice, 23 (3). 47-64.

Covin, J. G. ve Slevin, D. P. (1991). A Conceptual Model of Entrepreneurship as Firm Behavior. Entrepreneurship Theory and Practice, 16 (1). 7-25.

Culhane, J. H. (2003). The Entrepreneurial Orientation-Performance Linkage in High Technology Firms: An International Comperative Study. Thesis for The Degree of Doctor of Philosophy, Graduate School of The University of Massachuetts Amherst.

Çetindamar, D. (2002). Türkiye'de Girişimcilik. TÜSİAD Yayınlar, 33.

Demirez, M. (2005). Kosgeb Girişimciliüi Gelistirme Merkę̧i Müdürlïğ̈ Yaymlar, Ankara. www.kosgeb.gov.tr [Erişim: 10 Şubat 2019].

Durukan, T. (2005). Küresellesme ve Cokuluslu Issletmecilik. Ankara: Nobel Yayınları.

Durukan, T. (2006). Dünden Bugüne Girișimcilik ve 21. Yüzyllda Girișimciliğin Önemi. Girișimcilike ve Kalkinma Dergisi, cilt 1 sayı 2. 25-37.

Guth, W. D. ve Ginsberg, A. (1990). Introduction: Corporate Entrepreneurship. Strategic Management Journal, 11 (5). 5-15.

Gül, H. (2005). Bilgi Toplumu Liderlĭ̈i Karizmatik Liderliğin Sonu Olur mu? www.bilgiyonetimi.org/cm/pages/mkl/_gos.php?nt=223. [Erişim: 10 Şubat 2019].

Hisrich, R. ve Peters, M. (2001). Entrepreneurship. $5^{\text {th }}$ Edition, McGraw Hill Higher.

Huff, J. O.; Huff, A. S. ve Thomas, H. (1992). Strategic Renewal and The Interaction of Cumulative Stress and Inertia. Strategic Management Journal, 13. 55-75.

Jones, G. R. ve Butler, J. E. (1992). Managing Internal Corporate Entrepreneurship: An Agency Theory Perspective. Journal of Management, 18 (4). 733-749.

Knight, G. (1997). Cross-Cultural Reliability and Validiry of A Scale To Measure Firm Entrepreneural Orientation. Journal of Business Venturing, 12 (3). 213-225.

Küçükaltan, D. (2009). Genel Bir Yaklaşımla Girişimcilik. Girişimcilik ve Kalkınma Dergisi, cilt 4 sayı 1. 21-28.

Luchsinger, V. ve Bagby, D.R. (1987). Entrepreneurship and Intrapreneurship: Behaviors, Comparisons and Contrasts.S.A.M. Advanced Management Journal, 52 (3), 10-13.

Lumpkin, G. T. ve Dess, G. G. (1996). Clarifying the Entrpreneural Orientation Cunstruct and Linking It To Performance. Academy of Management Review, 21 (1). 135-172.

Lumpkin, G. T. ve Dess, G. G. (2001). Linking Two Dimensions of Entrpreneural Orientation to Firm Performance: The Moderating Role of Environment and Industry Life Cycle. Journal of Business Venturing, 16 (5). 429-451.

MacMillan, I. C. ve George, R. (1985). Corporate Venturing: Challenges for Senior Manager. Journal of Business Strategy, 5 (3). 34-43. Inc.

McDaniel, A. B. (2002). Entrepreneurship and Innovation: An Economic Approach, New York: M. E. Sharpe

McKinney, G. ve McKinney, M. (1989). Forget The Corporate Umbrella Entrepreneurs Shine in The Rain. Sloan Management Review, 30 (4). 77-82. 
Miles, M. P. ve Covin, J. G. (2002). Exploring The Practice of Corporate Venturing: Some Common Forms and Their Organizational Implications. Entrepreneurship Theory and Practice, 26 (3). 21-40.

Miller, D. ve Friesen, P. H. (1983). Strategy-Making and Environment: The Third Link. Strategic Management Journal, 4 (3). 221-235.

Morris, M. H. ve Kuratko, D. F. (2002). Corporate Entrepreneurship: Entrpreneurai Development within Organizations. Florida: Harcourt College Publishers.

Müftüoğlu, M. T. (2004). Girişimcilik. Eskişehir: AÖF Yayınları.

Naktiyok, A. (2004). İ Girişimcilik. İstanbul: Beta Yayınlan.

Pinchot, G. (1985). Intrapreneuring. New York: Harper and Row.

Pinnington, A. ve Haslop, D. (1995). Team Leader Autonomy In New Product Development. Management Decision, 33 (9). 5-11.

Raelin, J. A. (1989). An Anotomy of Autonomy: Managing Professionals. The Academy of Management Executive, 3 (3). 216-228.

Renewal: Mobilising Renewal Journeys in Multiunit Firms. Longe Range Planning, 34. 159-178.

Roberts, D., Peters, P.M., Shepherd, A.D. (2005). Definition of Entrepreneur Today. New York: McGrawHill Irwin.

Robinson, J. (2014). The 7 Traits of Successful Entrepreneurs. www.entrepreneur.com/article/230350. [Erişim: 12 Ocak 2019].

Rule, E. G. ve Irwin, D. W. (1988). Fostering Intrapreneurship: The New Competitive Edge. The Journal of Business Strategy, 9 (3). 44-47.

Schollhammer, H. (1982). Internal Corporate Entrepreneurship. Prentice-Hall, Englewood Cliffs, NJ. 209229.

Schumpeter, J. A. (1911). The Theory of Economic Development. An Inquiry into Profits, Capital, Credit, Interest and the Business Cycle. Translated by R. Opie, and published by Oxford University Press (1963), 66.

Shrader, R. C. ve Simon, M. (1997). Corporate Versus Independent New Ventures: Resource, Strategy, and Performance Differences. Journal of Business Venturing, 12 (1), 47-66.

Stevenson, H. H. ve Jarillo, J. C. (1990). A Paradigm of Entrepreneurship: Entrepreneurial Management. Strategic Management Journal, 11 (7). 17-27.

Stopford, J. M. ve Baden-Fuller, C. W. F. (1994). Creating Corporate Entrepreneurship. Strategic Management Joumal, 15 (7). 521-536.

Sönmez, A. ve Toksoy, A. (2014). Türkiye'de Girişimcilik ve Türk Girişimci Profili Üzerine Bir Analiz. Yönetim ve Ekonomi, 21 (2), 41-58.

Titiz, T. (1994). Girişimcilik. Ankara: İnkilap Kitabevi.

Vesper, K. H. (1984). Three Faces of Corporate Entrepreneurship, Frontiers of Entrpreneurship Research. Babson College, Wellesley, MA.

Volberda, H. W.; Baden-Fuller, C. ve Van Den Bosch, A. J. (2001). Mastering Strategic

Wiklund, J. ve Shepherd, D. (2005). Entrepreneurial Orientation and Small Business Performance: A Configurational Approach. Journal of Business Venturing, 20 (1). 71-91.

Zahra, S. A. (1991). Predictors and Financial Outcomes of Corporate Entrepreneurship: An Exploratory Study. Journal of Business Venturing, 6 (4). 259-285.

Zahra, S. A. (1993a). Environment, Corporate Entrepreneurship, and Financial Performance: A Taxonomic Approach. Journal of Business Venturing,8 (4). 319-340.

Zahra, S.A. (1993b). New Product Innovation in Established Companies: Associations with Industry and Strategy Variables. Entrpreneurship Theory and Practice, 18 (2). 47-67.

Zahra, S. A. (1993c). A Conceptual Model of Entrepreneurship As Firm Behavior: A Crituque and Extension. Entrepreneurship Theory and Practice, 17 (4). 5-21.

Zahra, S. A. (1995). Corporate Entrepreneurship and Financial Performance: The Case of Management Leveraged Buyouts. Journal of Business Venturing, 10 (3). 225-247.

Zahra, S. A. ve Pearce, J. A. (1994). Corporate Entrepreneurship in Smaller Firms: The Role of Environment, Strategy and Organization. Entrepreneurship, Innovation and Change, 3 (1). 31-44. 